\title{
Characterization of factor XIIIa positive dermal dendritic cells in normal and inflamed skin
}

\author{
R.CERIO, C.E.M.GRIFFITHS, * K.D.COOPER * B.J.NICKOLOFF^† AND \\ J.T.HEADINGTON*†
}

Institute of Dermatology, St John's Hospital for Diseases of the Skin, University of London, U.K., * Departments of Dermatology and +Pathology, University of Michigan Medical Center, Ann Arbor, MI, U.S.A.

Accepted for publication 17 April 1989

\section{SUMMARY}

The immunocytochemical identification and characterization of indigenous dermal dendritic cells (dermal dendrocytes) using a rabbit polyclonal antibody to clotting enzyme factor XIII subunit A (FXIIIa) was carried out on normal and inflamed human cutaneous tissue. The immunophenotype of FXIIIa positive dendritic cells was analysed with a panel of 18 monoclonal antibodies using immunoperoxidase and double immunofluorescence staining techniques.

The antibody against FXIIIa detected highly dendritic dermal cells located particularly in the upper reticular and papillary dermis. Double fluorescence microscopy showed that FXIIIa positive cells were bone marrow derived $\left(\mathrm{HLe}-\mathrm{I}^{+}\right)$and co-expressed monocyte, macrophage or antigen presenting cell markers $\left(\mathrm{HLA}_{-} \mathrm{DR}^{+}, \mathrm{LFA}_{-}{ }^{+}, \mathrm{HLA}_{-} \mathrm{DQ}^{+}, \mathrm{OKM}_{5}{ }^{+}, \mathrm{Mo} \mathrm{I}^{+}\right.$, Mono$\mathrm{I}^{+}$, Leu $\mathrm{M}_{3}{ }^{+}$). No labelling was obtained with cell markers for Langerhans cells (CDI), T lymphocytes ( $\mathrm{CD}_{2}$ ), granulocytes (LeuMr) fibroblasts ( $\mathrm{Te}_{7}$ ), intercellular adhesion moleculeI (ICAM-I) or endothelial cells (Factor VIII related antigen).

Gamma interferon induced increased expression of HLA-DR and co-expression of ICAM-I on $\mathrm{FXIIIa}^{+}$dermal dendritic cells in normal skin in organ culture. Moreover, in benign inflammatory dermatoses such as atopic eczema and psoriasis there was an increased number of $\mathrm{FXIIIa}^{+}, \mathrm{DR}^{+}, \mathrm{ICAM}_{-} \mathrm{I}^{+}$cells in the upper dermis and foci of FXIIIa ${ }^{+}$cells in the epidermis closely associated with lymphocytes.

FXIIIa positive cells in human skin represent a specific population of bone-marrow dermal dendritic cells, distinct from Langerhans cells, that share some features common to mononuclear phagocytes (monocyte/macrophages). In addition, the detection of HLA-DQ on $48 \%$ of $\mathrm{FXIIIa}^{+}$cells and the lack of OKMI in combination with high $\mathrm{OKM}_{5}$ expression suggests an antigen-presenting cell phenotype.

Correspondence: Dr Rino Cerio, Institute of Dermatology, St John's Hospital for Diseases of the Skin, 5 Lisle Street, London $\mathrm{WC}_{2} \mathrm{H} 7 \mathrm{BJ}$, U.K. 
There is increasing phenotypic and functional evidence for the recognition of several dendritic antigen-presenting cells (APC) which are both lymphoid and non-lymphoid associated. Well characterized lymphoid APCs include dendritic reticulum cells, interdigitating dendritic cells ${ }^{1}$ and follicular dendritic cells. ${ }^{2}$ Circulating immunocompetent dendritic cells have also been found in human peripheral blood ${ }^{3,4}$ and afferent lymph. ${ }^{5}$ Non-lymphoid immunocompetent dendritic cells include Langerhans cells, ${ }^{6}$ collagen associated dendritic cells ${ }^{7.8}$ as well as dendritic cells in the synovium, ${ }^{9}$ respiratory tract, ${ }^{10}$ thyroid gland ${ }^{11}$ and heart. ${ }^{12}$ It has been suggested that macrophages and dendritic cells have a common origin in the human yolk sac but diverge early in foetal development. ${ }^{13}$ Activation and proliferation of antigen-specific effector $\mathrm{T}$ cells are dependent upon recognition of antigens by APC which bear class II major histocompatibility complex (MHC) antigens. These can be expressed on both epidermal and dermal cells including Langerhans cells, ${ }^{6}$ endothelial cells, ${ }^{14} \mathrm{~B}$ cells, ${ }^{15}$ melanophages, ${ }^{16-18}$ as well as dermal ${ }^{19,20}$ and other dendritic cells. ${ }^{3,21,22}$

The derivation and role of the $\mathrm{DR}^{+}$dermal dendritic cell is still uncertain. Using enzyme histochemical and immunochemical techniques it has been shown that many dermal dendritic cells share features with mononuclear phagocytic cells (macrophages) and have a phagocytic function. ${ }^{8}$ In addition, as in humans, class II MHC bearing dermal cells distinct from endothelial cells are present in mouse skin, and function as APCs in vitro and initiate primary contact hypersensitivity responses to contact allergens. ${ }^{19.20}$

Recently, there has been renewed interest in the cytoplasmic identification of the subunit A of the clotting proenzyme factor XIII (FXIIIa). The protein is expressed in histiocytic reticulum cells (sinus lining cells) of lymphoid tissue, ${ }^{23}$ peripheral blood monocytes, ${ }^{24-26}$ peritoneal macrophages, ${ }^{27}$ reactive fibroblasts, ${ }^{28}$ and recently in dermal dendritic cells. ${ }^{29}$ Nemes et al. ${ }^{30}$ regard this protein as a marker of phagocytic function.

The aim of this study was to further characterize FXIIIa positive dendritic cells in normal and inflamed human cutaneous tissue using immunocytochemical techniques. We have investigated the lineage of FXIIIa positive dermal dendritic cells including their relationship to Langerhans cells and monocyte/macrophages, and also whether these cells could be stimulated by gamma interferon (IFN- $\gamma$ ) to express intercellular adhesion molecule-I (ICAM-I) or CDI. We also looked at the role of FXIIIa ${ }^{+}$cells in inflammatory dermatoses.

\section{METHODS}

\section{Skin biopsies}

Six normal neonatal foreskins were obtained at routine circumcision. Punch biopsies of skin (6 $\mathrm{mm}$ ) were performed on three healthy volunteers and on lesional skin from patients with chronic plaque-type psoriasis (8) and atopic eczema (10).

Specimens from both foreskin and adult skin biopsies were divided into $2-\mathrm{mm}$ portions. One portion was embedded in gum tragacanth (Sigma Chemical Co., St Louis, MO, U.S.A.), mounted on cork and frozen in isopentane, cooled in liquid nitrogen, and stored, wrapped in aluminium foil at $-70^{\circ} \mathrm{C}$ until use. Other divided portions were incubated in $5 \mathrm{ml}$ of Dulbecco's modified Eagle's medium (Gibco Laboratories, Grand Island, NY, U.S.A.) supplemented with 10\% heat-inactivated fetal calf serum (Gibco Laboratories) either alone or with recombinant IFN- $\gamma$ (Dr M. Shephard, Genentech Inc., San Francisco, CA, U.S.A.) (specific activation$\mathrm{I} \cdot 7 \times \mathrm{IO} \mathrm{U} / \mathrm{mg}$, normal concentration of $\mathrm{I} 200 \mu / \mathrm{ml}$ ). Incubated specimens were maintained with periodic agitation in a humidified incubator with $5 \% \mathrm{CO}_{2} / 95 \%$ air at $37^{\circ} \mathrm{C}$ for $48 \mathrm{~h}$, then embedded as described above. 
TABLE I. Antibodies directed towards human mononuclear cells

\begin{tabular}{|c|c|}
\hline Antibodies & Specificity \\
\hline \multicolumn{2}{|l|}{$\begin{array}{l}\text { Polyclonal } \\
\quad \text { Anti FXIIIaऽS }\end{array}$} \\
\hline $\begin{array}{l}\text { Anti FVIII related } \\
\text { antigen (ra) }\end{array}$ & Endothelial cells \\
\hline \multicolumn{2}{|l|}{ Monoclonal } \\
\hline HLe-I & All bone-marrow derived cells ${ }^{\star}$ \\
\hline Anti HLA-DR/Leuro & Class II MHC protein antigen (DR/DQ)* \\
\hline Leu6 & $\begin{array}{l}\text { Cortical thymocytes } \\
\text { Langerhans cells }(\mathrm{CDr})^{\star}\end{array}$ \\
\hline LFA-I & $\begin{array}{l}\text { Lymphocyte function } \\
\text { associate antigen-I (Lymphocyte/monocytes) } \dagger\end{array}$ \\
\hline Leusb & $\mathrm{T}$ cells $\left(\mathrm{CD}_{2}\right)^{\star}$ \\
\hline LeuMI & Myelomonocytes * \\
\hline $\mathrm{LeuM}_{3}$ & Monocyte/macrophage antigen $\left(\mathrm{CD}_{14}\right)^{\star}$ \\
\hline LeuMs & Monocyte/macrophage antigen ${ }^{\star}$ \\
\hline Avidin & Mast cells* \\
\hline Anti FVIII ra & Endothelial cells $\ddagger$ \\
\hline OKMI & Monocyte antigen $\left(\mathrm{C}_{3}\right.$ bi receptor $) \int$ \\
\hline $\mathrm{OKM}_{5}$ & Monocyte and platelet antigen $\S$ \\
\hline Mo I & $\begin{array}{l}\text { Myeloid antigen or monocytes, } \\
\text { granulocytes and null cells } \neq\end{array}$ \\
\hline $\mathrm{Mo}_{2}$ & Myeloid antigen or monocytes and plateletsł \\
\hline Mono-I & Monocyte/macrophage antigen \\
\hline RFDI $_{I}$ & Interdigitating, reticulum cells ${ }^{\star \star}$ \\
\hline $\mathrm{Te}_{7}$ & Fibroblasts $\dagger \dagger$ \\
\hline$R R-I / I$ & Intercellular adhesion molecule-I (ICAM-I) $\ddagger$ \\
\hline
\end{tabular}

Source.

${ }^{\star}$ Beckton Dickinson, Sunnyvale, CA, U.S.A.

† Dr C.Clayberger, Stanford University.

¥ Coulter Immunology, Hialeah, FL, U.S.A.

$\$$ Ortho Immunodiagnostics, Raritan, NJ, U.S.A.

If Bethesda Laboratories/Gibco, Gaithersburg, MD, U.S.A.

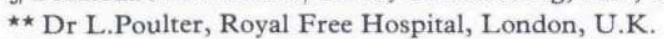

t† Dr B.Haynes, Duke University, Durham, NC, U.S.A.

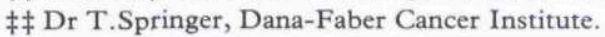

If Behringwerke, Marburg, F.R.G.

If Atlantic Antibodies, Scarborough, ME, U.S.A.

\section{Double immunofluorescence labelling}

Five micron cryostat sections were cut and air-dried. A panel of antibodies to various human mononuclear cell types was employed in an indirect immunofluorescence labelling technique (Table I). Skin sections were incubated with primary antibodies for $45 \mathrm{~min}$ followed by three 5min washes in phosphate-buffered saline (PBS). Second-step staining was performed with the use of goat anti-mouse IgG (I/40) (heavy- and light-chain-specific-affinity purified, humanserum absorbed and fluorescein conjugated; Kirkegaard and Perry, Gaithersburg, MD, U.S.A.) for $30 \mathrm{~min}$. Labelling for detection of polyclonal rabbit anti-FXIIIa or factor VIII (FVIII) related antigen $(\mathrm{I} / 40)$ and mouse monoclonal antibodies $(\mathrm{I} / 20)$ was accomplished using 
rhodamine on fluorescein-conjugated goat anti-rabbit IgG (I/20) (Tago Inc., Burligame, CA, U.S.A.) in a similar manner. Endothelial cells were visualized with a directly fluoresceinconjugated goat anti-human factor VIII related antigen (Atlantic Antibodies, Scarborough, ME, U.S.A.).

Double-labelling immunofluorescence microscopy was performed by visualizing bound antibody against FXIIIa with fluorescein-conjugated $\mathrm{F}(\mathrm{ab}) 2$ goat anti-rabbit IgG (Tago Inc.) followed by mouse monoclonal antibody and normal rabbit IgG to block cross-reactivity of the conjugated antibodies; the mouse antibody then being visualized with rhodamine-conjugated goat anti-mouse IgG. (Cappel Laboratories, Cockranville, PA, U.S.A.). Control sections were incubated in normal rabbit serum instead of primary polyclonal antibody and in mouse serum instead of monoclonal antibodies to verify the absence of xerogenic cross reactivity of the conjugated antibodies. Mast cells were visualized using avidin-conjugated to fluorescein. All dilutions were made up in PBS with $10 \%$ fetal calf serum.

Evaluation of fluorescence was performed with a Nikon microscope equipped with epifluorescence and appropriate filters. Identical fields were photographed and the percentage of each cell marker was analysed against labelling with FXIIIa.

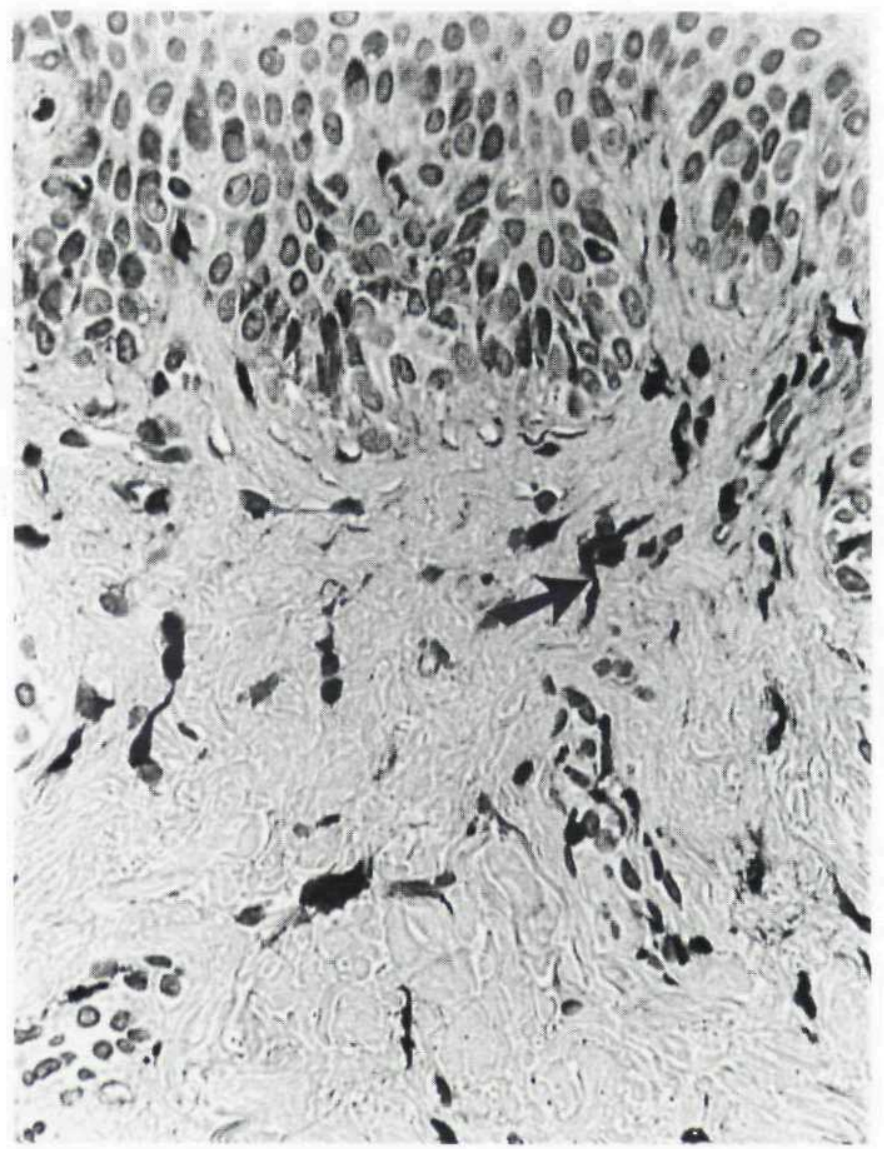

FIGURE I. Factor XIIIa positive dendritic cells within the dermal papillae (arrow) in normal skin $(\times 300)$. 

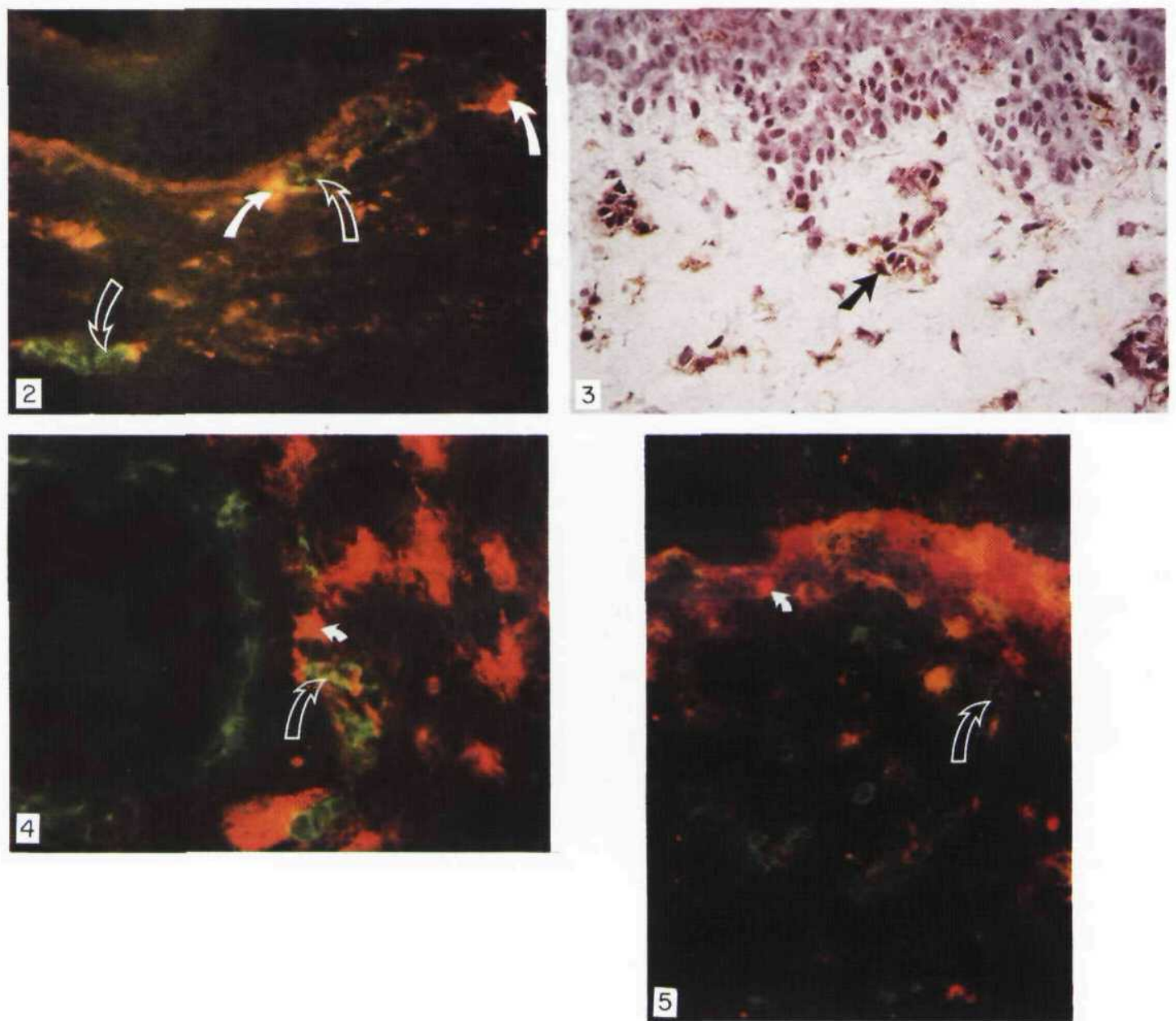

FIGURE 2. Negative double-indirect immunofluorescence labelling with FXIIIa (rhodamine, closed arrow) and FVIII related antigen (fluorescein, open arrow) in normal skin ( $\times$ I 50 ).

FIGURE 3. HLe immunoperoxidase labelling of dermal dendritic cells (arrow) in normal skin ( $\times$ I50).

FIGURE 4. Negative double immunofluorescence labelling with FXIIIa (rhodamine, closed arrow) and Leu6 (fluorescein, open arrow) in normal skin ( $\times 180)$.

FIGURE 5. Positive double immunofluorescence labelling (shown in yellow/orange) with FXIIIa (rhodamine, closed arrow) and HLA-DR (fluorescein, open arrow) in normal skin ( $\times$ I 80 ).

\section{Immunoperoxidase labelling}

Fresh frozen cryostat sections $(5 \mu \mathrm{m})$ were cut and dried and fixed in acetone at $4{ }^{\circ} \mathrm{C}$ for $10 \mathrm{~min}$. Staining was accomplished with an avidin-biotin peroxidase technique (Vectastain ABC mouse kit-Vector Labs., Inc., Burlingame, CA, U.S.A.) employing the monoclonal antibodies listed in Table I. The optimal concentrations of these monoclonal antibodies were determined to 
provide maximal specific labelling with minimal non-specific or background staining (data not shown). Either 3,3'-diaminobenzidene tetrahydrochloride or 3-amino-9-ethycarbazole were used as the chromogen. The sections were counterstained in $\mathrm{I}_{0}^{\circ}$ haematoxylin. FXIIIa was also identified in routine paraffin-processed specimens. Sections were de-waxed in xylene, followed by rehydration in graded alcohols. Subsequently, slides were trypsinized (trypsin [Sigma, St. Louis, MO, U.S.A.] $0.1 \%$ in $0.1 \% \mathrm{CaCl}_{2}$ in distilled water, $\mathrm{pH} 7.8$ for 10 min at $37^{\circ} \mathrm{C}$ ) and treated with $0.5 \% \mathrm{H}_{2} \mathrm{O}_{2}$ in absolute methanol for $30 \mathrm{~min}$ to block endogenous peroxidase activity. The sections were then labelled in the same way as cryostat specimens employing a Vectastain ABC rabbit kit. The primary FXIIIa rabbit antibody was applied at a dilution of I/ $200-1 / 400$.

\section{RESULTS}

\section{Normal skin}

$\mathrm{FXIIIa}^{+}$dermal dendritic cells could be demonstrated in both neonatal foreskin and adult skin. They were distributed mainly in the upper dermis but especially in the papillary dermis around superficial blood vessels (Fig. I). No labelling was seen in the epidermis in normal skin, nor in adnexal structures or neural tissue.

To determine the derivation of $\mathrm{FXIIIa}^{+}$cells in the dermis, double immunofluorescence labelling was carried out in both neonatal and adult skin with similar results. FXIIIa was not expressed by endothelial cells expressing FVIII related antigen (Fig. 2), or by fibroblasts expressing $\mathrm{Te} 7$ or by mast cells visualized by avidin-binding. However, $87 \%$ of FXIIIa ${ }^{+}$cells expressed the bone marrow derivation marker HLe-I. This was supported by HLe-I immunoperoxidase labelling of dermal dendritic cells (Fig. 3). Among bone marrow-derived cells FXIIIa ${ }^{+}$cells failed to express T lymphocyte (CD2) or Langerhans cell (CDI) markers (Fig. 4), but $85 \%$ did express HLA-DR (Fig. 5), LFA-I and $48 \%$ HLA-DQ, suggesting a

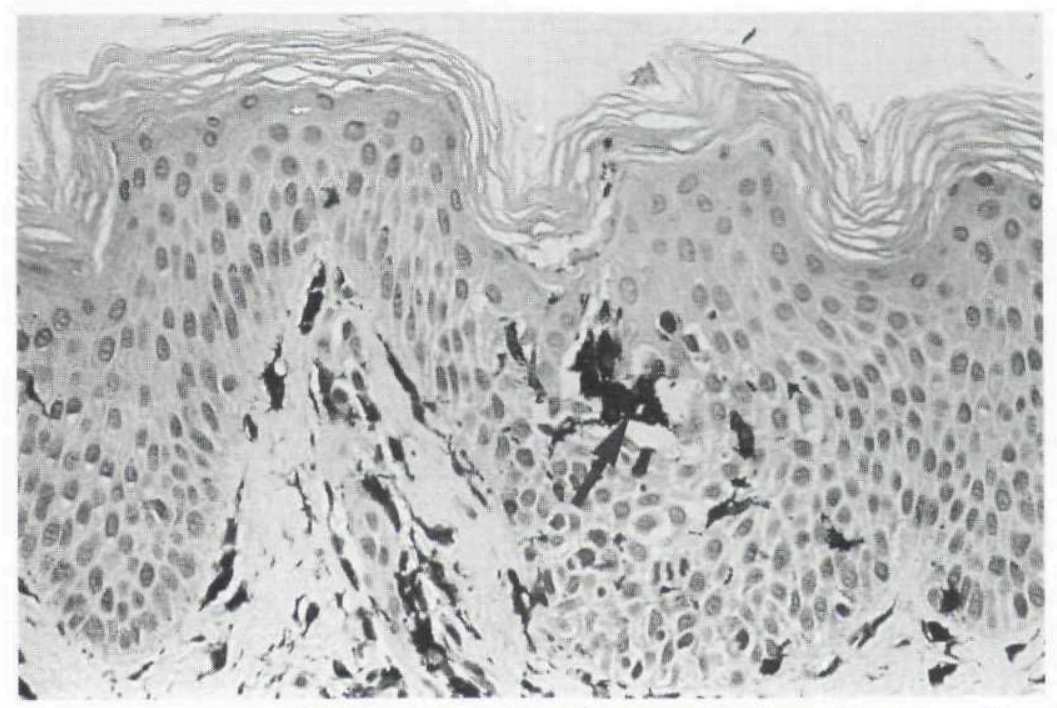

FIGURE 6. Immunoperoxidase labelling of dendritic cells (arrow) in abnormal epidermal location with polyclonal antibody FXIIIa in atopic eczema $(\times 320)$. 
monocyte/macrophage and/or dendritic APC lineage. The majority of FXIIIa ${ }^{+}$cells expressed some monocyte/macrophage antigens, i.e. $92 \% \mathrm{OKM}_{5}^{+}, 88 \% \mathrm{Mo} \mathrm{I}^{+}, 92 \%$ Mono- $\mathrm{I}^{+}$and $22 \%$ Leu $\mathrm{M}_{3}{ }^{+}$but lacked Leu $\mathrm{M}_{5}$, Leu MI and Mo2 expression. The detection of HLA-DQ on $48 \%$ of FXIIIa ${ }^{+}$cells and the lack of $\mathrm{OKMr}_{\mathrm{r}}$ in combination with high $\mathrm{OKM}_{5}$ expression suggests an APC phenotype. Unstimulated $\mathrm{FXIIIa}^{+}$cells did not co-express RFD-I or ICAM-I.

$\mathrm{OKM}_{5}$ is also expressed on some FVIII related antigen-positive endothelial cells in skin, ${ }^{18}$ raising the possibility of overlap between $\mathrm{FXIIIa}^{+}, \mathrm{OKM}_{5}{ }^{+}$cells and $\mathrm{FVIII}^{+}$endothelial cells. However, not all OKMs ${ }^{+}$cells expressed FXIIIa and none of the FVIII ${ }^{+}$endothelial cells were identified as positive for FXIIIa, indicating that $\mathrm{OKM}_{5}$ is expressed on at least two separate types of dermal cells.

These findings were confirmed using immunoperoxidase single-labelling techniques in cryostat sections of normal skin.

\section{Inflamed skin}

FXIIIa labelling of skin from benign inflammatory dermatoses such as atopic eczema and psoriasis compared to normal skin revealed an increase in the number of dermal dendritic cells. Numerous FXIIIa dendritic cells were demonstrated around superficial blood vessels particularly in atopic eczema (Fig. 6). In contrast to normal skin, foci of FXIIIa ${ }^{+}$dendritic cells were observed in the epidermis associated with lymphocytes, especially where spongiosis and vesicle formation were most evident (Fig. 7). In skin from patients with chronic plaque psoriasis the increase in FXIIIa ${ }^{+}$cells appeared to be confined to the papillary dermis, and in two cases dendritic processes from $\mathrm{FXIIIa}^{+}$cells were observed traversing the basement membrane into the epidermis, closely associated with inflammatory cells (Fig. 8). Individual positively labelled cells were also seen in the epidermis which appeared to originate from the dilated papillary blood vessels.

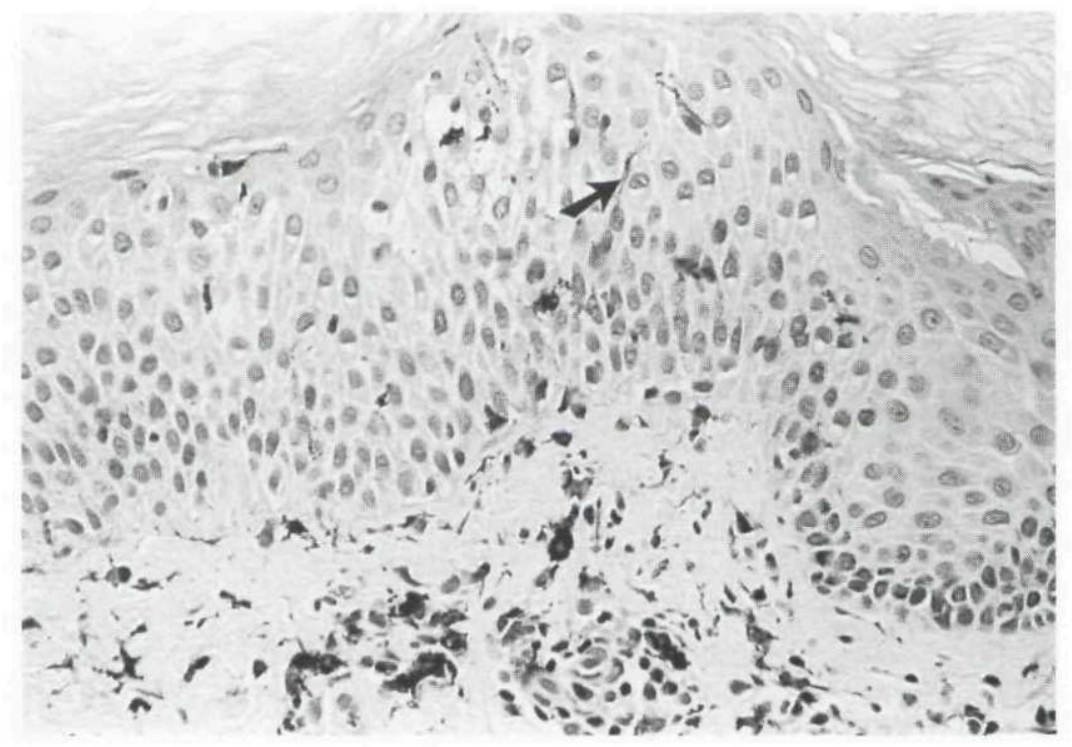

FIGURE 7. FXIIla immunoperoxidase labelling of dendritic cells (arrow) in atopic eczema $(\times 320)$. 


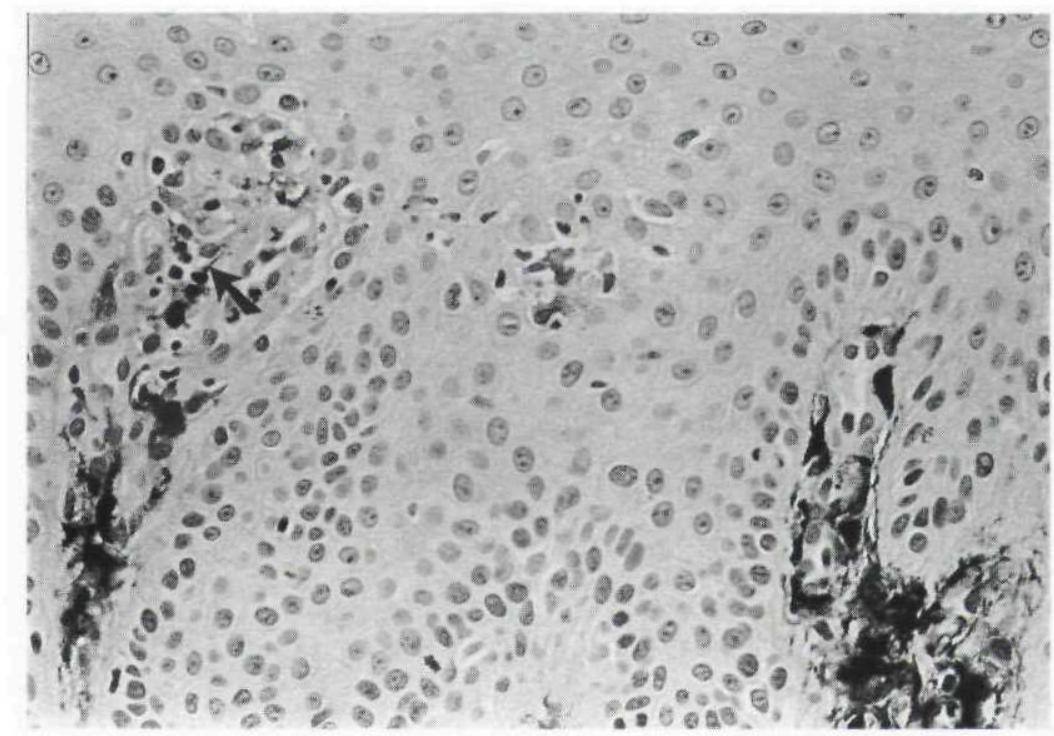

FIGURE 8. Immunoperoxidase labelling of dendritic cells (arrow) with FXIIIa in psoriasis ( $\times 320$ ).

In normal neonatal foreskin and adult skin in the modified organ culture system, ICAM-I expression was confined to endothelial cells but when stimulated with IFN- $\gamma$, ICAM-I was found to be induced on $\mathrm{FXIIIa}^{+}$dermal dendritic cells. Furthermore, there appeared to be increased expression of HLA-DR on these cells, although this was not quantified.

\section{DISCUSSION}

The findings in this study confirm the previous suggestion that FXIIIa is a cell marker for dermal dendrocytes, ${ }^{29,31}$ and provide phenotypic and functional evidence for the characterization of a bone marrow-derived HLA-DR ${ }^{+}$dermal dendritic cell population, distinct from Langerhans cells. In contrast to Langerhans cells they lack CDI and have been shown to be phagocytic. ${ }^{31}$ Unlike previous reports ${ }^{28}$ we have shown that in cutaneous tissue, $\mathrm{FXIIIa}^{+}$cells are not fibroblasts (i.e. $\mathrm{Te}^{-}$) which agrees with the recent report of negative FXIIIa labelling in fibrocollagenous cutaneous disorders. ${ }^{29} \mathrm{FXIIIa}^{+}$cells are bone marrow-derived cells with some of the cell surface antigens found on monocyte/macrophage subsets $\left(\mathrm{OKM}_{5}{ }^{+}, \mathrm{Mo} \mathrm{I}^{+}\right.$, Mono $\mathrm{I}^{+}$, Leu $\mathrm{M}_{3}^{+}$).

We suggest that $\mathrm{FXIIIa}^{+} \mathrm{OKM}_{5}{ }^{+}$dermal dendritic cells comprise a pluripotential population, capable under various circumstances of macrophage effector functions, ${ }^{16-18} \mathrm{APC}$ functions, ${ }^{19,21,32,33}$ and perhaps even differentiation into Langerhans cells upon migration into the epidermis. ${ }^{34}$ Recently, Weiss et al. ${ }^{18}$ have shown that dermal phagocytic cells, containing melanin, in inflammatory skin diseases demonstrate the surface phenotype of $\mathrm{CDI}^{-} \mathrm{DR}^{+}$, $\mathrm{OKM}_{5}{ }^{+}, \mathrm{OKMI}^{-}, \mathrm{APC}$ 's and activated macrophages $\left(\mathrm{Mo}_{3}{ }^{+}\right)$. These $\mathrm{OKM}_{5}{ }^{+}$dermal dendritic melanophages may represent the same subtype as detected by FXIIIa and may derive 
from them. Moreover, $\mathrm{CDr}^{-} \mathrm{DR}^{+}, \mathrm{OKM}_{5}{ }^{+}, \mathrm{OKMI}^{-}$melanophages have been demonstrated in human epidermis after ultraviolet light exposure and have been shown to have potent APC activity. ${ }^{16}$ The FXIIIa ${ }^{+}$dermal dendritic cells appear distinct however, in that they express Leu $\mathrm{M}_{3}$ and $\mathrm{Mor}$, whereas $\mathrm{CD}_{1}{ }^{-} \mathrm{DR}^{+} \mathrm{OKM}_{5}{ }^{+}$epidermal melanophages lack these two cell surface antigens. ${ }^{16}$ Similarly, increased $\mathrm{CD}_{\mathrm{I}}{ }^{-} \mathrm{DR}^{+}$subpopulations of epidermal cells have been demonstrated in psoriasis ${ }^{35,36}$ and recently, other inflammatory dermatoses. ${ }^{37,38}$ Ultrastructural studies have suggested that at least some of the $\mathrm{CD}_{\mathrm{I}}-\mathrm{DR}^{+}$epidermal dendritic cells were of the Langerhans cell lineage. Our studies have shown that $\mathrm{FXIIIa}^{+}$dermal dendritic cells can be induced by IFN- $\gamma$ to co-express ICAM-I. In inflamed skin such as atopic eczema and psoriasis, $\mathrm{FXIIIa}^{+}$cells appear to migrate from the papillary dermis into the epidermis in close proximity to lymphocytes and other inflammatory cells, probably by virtue of their ICAM-I positivity. We propose that some of the $\mathrm{CDI}^{-} \mathrm{DR}^{+}$epidermal dendritic cells are $\mathrm{FXIIIa}^{+}$. In $\mathrm{UV}$-induced inflammation the $\mathrm{CDI}^{-} \mathrm{DR}^{+}, \mathrm{OKM}_{5}^{+}, \mathrm{OKMI}^{-}$melanophages exhibited the capacity to present antigen and to activate autologous $\mathrm{T}$ cells in the absence of added antigens. ${ }^{16}$ Our immunophenotypic characterization suggests that $\mathrm{FXIIIa}^{+}$dermal dendritic cells may represent the cutaneous analogue of potent blood APC, described as a minor subset of monocytes with a phenotype $\mathrm{OKM}_{5}{ }^{+} \mathrm{OKMI}^{-} .32$ These cells may be responsible in a similar way for stimulating immunoregulatory $\mathrm{T}$ cells that modulate other immune responses. ${ }^{38-39}$ If FXIIIa ${ }^{+}$, Class II MHC bearing dermal dendritic cells are analogous to murine Class II MHC dermal dendritic cells, then they would be expected to process and present soluble and alloantigens to $\mathrm{T}$ cells ${ }^{17}$ and to be able to initiate allergic contact hypersensitivity responses. ${ }^{20}$

Expression of the antigen detected by $\mathrm{OKM}_{5}$ has also been shown on endothelial cells ${ }^{16}$ suggesting that FXIIIa might also be identified in endothelial cells. However, double staining studies with antifactor VIII related antigen showed that as with $\mathrm{OKM}_{5}{ }^{+}$melanophages, these bone marrow derived cells are distinct from endothelial cells. ${ }^{18}$

Functional studies with the modified organ skin culture ${ }^{41}$ showed that when stimulated by IFN- $\gamma$, FXIIIa positive dermal cells demonstrate increased expression of ICAM-I. The latter is an inducible glycoprotein found on vascular endothelial cells, mitogen-stimulated $\mathrm{T}$ lymphocytes, EBV transformed B cells and tissue macrophages ${ }^{42}$ and is important for leucocyte trafficking into tissues. ${ }^{43}$ ICAM-I is the ligand for lymphocyte function associated antigen-I (LFA-I) found on lymphocytes and monocytes. The expression of ICAM-I by the dermal dendrocyte may facilitate adhesive interactions with $\mathrm{T}$ lymphocytes as we have proposed for keratinocyte lymphocyte reaction. ${ }^{41,43}$ We have recently labelled fixed and unfixed cultured human fibroblasts for LFA-I and FXIIIa and there was no cell surface immunolabelling. Also, fibroblasts are LFA-3 positive but neither LFA-I nor FXIIIa could be induced on fibroblasts with either IFN- $\gamma$ or IFN- $\alpha$.

In conclusion, $\mathrm{FXIIIa}^{+}$dendritic cells in normal skin and in some examples of inflammatory cutaneous diseases represent a specific immunological cell population with multiple potential functional properties as defined by their immunophenotype. Moreover, cytoplasmic FXIIIa can be detected in routine paraffin-embedded sections allowing superior preservation of morphological detail which permits a retrospective study of this cell marker in a wide spectrum of cutaneous diseases. There is evidence to support the hypothesis that dermal dendritic cells, or important subsets thereof, constitute an immunologically competent cell population which is indigenous to the dermis if not to all collagen-rich tissues. ${ }^{29,31}$ It would be reasonable for dermal immunologic competence to be complementary to epidermal immunologic function, particularly in a wide variety of immunologically mediated inflammatory dermatoses. Recently, 
we have reported that $\mathrm{FXIIIa}^{+}$dermal dendritic cells are increased in a wide variety of inflammatory, fibrohistiocytic and granulomatous dermatoses including AIDS-associated Kaposi's sarcoma also suggesting that these cells have an important role in the pathophysiology of these disorders. ${ }^{44,45}$

\section{ACKNOWLEDGMENTS}

RC and CEMG were partially supported by travelling fellowships from the British Association of Dermatologists. KDC was supported in part by NIH grant No. Ko8ARoI770-03, the Veterans Administration Medical Research Service and BJN by NIH grant No. AR 389570.

\section{REFERENCES}

I Witmer MD, Steinman RM. The anatomy of peripheral lymphoid tissue with emphasis on accessory cells. Light microscopic imunocytochemical studies of mouse spleen, lymph node and Peyer's patch. Am f Anat 1984; 170: 46581 .

2 Klaus GGB, Humphrey JH,Kunkl A, Doneworth DW. The follicular dendritic cell: its role in antigen presentation in the generation of immunological memory. Immunol Rev 1980; 53: 3-28.

3 Van Voorhis WC, Hair L, Steinman R, Kaplan G. Human dendritic cells: enrichment and characterization from peripheral blood. $f$ Exp Med 1982; 155: $1172-87$.

4 Knight SC, Farrant J, Bryant A et al. Non-adherent, low density cells from human peripheral blood contain dendritic cells and monocytes, both with veiled morphology. Immunology 1986; 57:595-603.

5 Fossum S. Lymph-borne dendritic leucocytes do not recirculate but enter the lymph node paracortex to become interdigitating cells. Scand f Immunol 1988; 27: 97-105.

6 Stingl G, Tamaki K, Katz S. Origin and function of epidermal Langerhans cells. Immenol Rev 1980; 53: 149-74.

7 Hart DNS, Fabre JW. Demonstration and characterization of Ia-positive dendritic cells in the interstitial connective tissue of rat heart and other tissues, but not brain. I Exp Med 1981; 154: 347-9.

8 Headington JT. The dermal dendrocyte. In: Advances in Dermatology (Callen JP, Dahl MV, Golitz LE et al. eds), Vol. I Chicago: Chicago Year Book Medical Publishers Inc., 1986; 159-71.

9 Klareskog L, Forsum U, Malnnas Tjernlund et al. Appearance of anti-HLA-DR ${ }^{-}$reactive cells in normal and rheumatoid synovial tissue. Scand $\mathcal{F}$ Immunol 1981; 14: 183-92.

Io Sertl K, Takemura T, Tschachler $\mathrm{E}$ et al. Dendritic cells with antigen-presenting capability reside in airway epithelium, lung parenchyma and visceral pleura. I Exp Med 1986; 163: 436-51.

II Kabel PJ, Voorbij HA, DeHaan M et al. Intrathyroidal dendritic cells. 7 Clin Endocrinol Metab 1988; 66: 199-209.

I2 Lesczynski D, Rensbonon R, Hayry P. Turnover of dendritic cells in rat heart. Scand f Immunol 1985; 22: 35 I-5.

I3 Janossy G, Bofill M, Poulter LW et al. Separate ontogeny of two macrophage-like accessory cell populations in the human foetus. I Immunol 1986; 136: 4354-6r.

14 Hirschberg M, Evenson S, Henriksen T, Thorsby E. The human mixed lymphocyte-endothelial culture interaction. Transplantation 1975; 19: 495-504.

15 Ashwell J, DeFranco A, Paul W, Schwartz R. Antigen presentation by resting B cells. Radiosensitivity of antigen presentation function and two distinct pathways of T-cell activation. 7 Exp Med 1984; 154: 88 I-905.

16 Cooper KD, Neises GR, Katz SI. Antigen-presenting $\mathrm{OKM}_{5}{ }^{+}$melanophages appear in human epidermis after ultraviolet radiation. F Invest Dermatol 1986; 86: 363-70.

17 Cooper KD, Duraiswamy N, Kang S et al. Murine dermal cells in suspension contain T cell-activating antigen presenting cells. I Invest Dermatol $1987 ; 88: 482$.

18 Weiss JS, James WD, Cooper KD. Melanophages in inflammatory skin disease demonstrate the surface phenotype of $\mathrm{OKMS}_{5}{ }^{+}$antigen-presenting cells and activated macrophages. F Am Acad Dermatol 1988; 19: 633-41.

I9 James WD, Cooper KD, Todd RF et al. Inflammatory acquired oral hyperpigmentation: association with melanophages demonstrating phenotypic characteristics of antigen presenting cells and activated monocytes. $f \mathrm{Am}$ Acad Dermatol 1987; 16: 220-6.

20 Cooper $\mathrm{KD}$. Tse $\mathrm{Y}$, Cutaneous dermal $\mathrm{Ia}^{+}$cells are capable of initiating delayed type hypersensitivity responses. Clin Res 1988; 36: 834A.

21 Steinman R, Nussenzwerg M. Dendritic cells: features and function. Immunol Rev 1980; 83: 122-67.

22 Hoefsmit ECM, Duijuestijn AM, Kamperdijk EWA. Relation between Langerhans' cells, veiled cells and interdigitating cells. Immunobiology 1982; 161: 255-65. 
23 Nemes Z, Thomazy V, Adany R, Muszbek L. Identification of histocytic reticulum cells by the immunohistochemical demonstration of Factor XIII (F-XIIIa) in human lymph nodes. F Pathol 1986; 149: 121-132.

24 Muszbek L, Adany R, Szegedi G et al. Factor XIII of blood coagulation in human monocytes. Thrombosis Res 1985 ; 37: 401-10.

25 Henriksson P, Becker S, Lynch G, McDonagh J. Identification of intracellular Factor XIII in human monocytes and macrophages. $f$ Clin Invest $1985 ; 76: 528-34$.

26 Weisberg LJ, Shiu DT, Conkling PR, Shuman MA. Identification of normal human peripheral blood monocytes and liver as sites of synthesis of coagulation Factor XIIIa-chain. Blood 1987; 70: 579-582.

27 Adany R, Belkin A, Vasilevskaya T, Muszbek L. Identification of blood coagulation Factor XIII in human peritoneal macrophages. Eur f Cell Biol 1985; 38: 171-173.

28 Fear JD, Jackson P, Gray C et al. Localization of Factor XIII in human tissues using an immunoperoxidase technique. 7 Clin Pathol 1984; 37: 560-563.

29 Cerio R, Spaull JR, Wilson Jones E. Histiocytoma cutis: a tumour of dermal dendrocytes (dermal dendrocytoma). Br f Dermatol 1989; 120: 197-206.

30 Nemes Z, Thomazy V. Factor XIIIa and the classic histiocyte markers in malignant fibrosis histiocytoma: a comparative immunohistochemical study. Hum Pathol 1988; 19: 822-9.

3I Cerio R, Spaull JR, Wilson Jones E. Identification of Factor XIIIa in cutaneous tissue. Histopathology 1988; 13: $362-3$.

32 Shen HH, Talle MA, Goldstein G, Chess L. Functional subsets of human monocytes derived by monoclonal antibodies: a distinct subset of monocytes contains the cells capable of inducing the autologous mixed lymphocyte culture. F Immunol r983; 130: 698-705.

33 Sontheimer RD. Isolation and preliminary functional characterization of dermal macrophages from newborn human foreskin. Clin Res 1988; 36: 696A.

34 Murphy GF, Messadi D, Fonferko E, Hancock WW. Phenotypic transformation of macrophage to Langerhans cells in the skin. Am $\mathcal{F}$ Pathol 1986; 123: 401-6.

35 Baker BS, Griffiths CEM, Lambert S et al. The effect of cyclosporin A on T lymphocytes and dendritic subpopulations in psoriasis. $\mathrm{Br}$ f Dermatol 1987; 116: 503-510.

36 Baadsgaard O, Gupta A, Taylor S et al. Psoriasis epidermal cells demonstrate increased numbers and functions of non-Langerhans cell antigen presenting cells. F Invest Dermatol 1989; 92: 190-5.

37 Baker BJ, Lambert S, Powles AV et al. Epidermal DR ${ }^{+} \mathrm{T}^{-}$dendritic cells in inflammatory skin diseases. Acta Derm Venereol (Stockh) I988; 68, 209-17.

38 Cooper KD, Fox P, Neises G, Katz SI. Effects of ultraviolet radiation on human epidermal cell alloantigen presentation: initial depression of Langerhans cell-dependent function is followed by appearance of $\mathrm{T}^{-} \mathrm{DR}^{+}$cell which enhance epidermal alloantigen presentation. $f$ Immunol 1984; 134: 129-137.

39 Pazderka F, Angeles A, Kovithavongs T, Dossetor JB. Induction of suppressor cells in autologous mixed lymphocyte culture (AMLC) in humans. Cell Immunol 1983; 75: 122-33.

40 James SP, Tenokida GG, Graeff AS et al. Immunoregulatory function of T cells activated in the autologous mixed lymphocyte reaction. I Immunol 198I; 127: 2605-9.

4I Griffiths CEM, Voorhees J, Nickoloff BJ. Characterization of intercellular adhesion molecule-I and HLA-DR expression in normal and inflamed skin: modulation by recombinant gamma interferon and tumor necrosis factor. f Am Acad Dermatol r989, 20: 617-29.

42 Wantzin GL, Ralfkiaer E, Lisby S, Rothlein R. The role of intercellular adhesion molecules in inflammatory skin reactions. $\mathrm{Br}$ f Dermatol I988; 11 9: $14 \mathrm{I}-5$.

43 Nickoloff BJ. The role of gamma interferon in cutaneous trafficking of lymphocytes with emphasis on molecular and cellular adhesion events. Arch Dermatol 1988; 124: I835-43.

44 Nickoloff BJ, Griffiths CEM. Factor XIIIa expressing dermal dendrocytes are increased in AIDS associated Kaposi's sarcoma. Science I989; 243: 1736-7.

45 Cerio R, Spaull J, Oliver GF, Wilson Jones E. A study of Factor XIIIa and Mac 387 immunolabelling in normal and pathological skin. Am $\mathcal{F}$ Dermpath 1989 (in press). 
This document is a scanned copy of a printed document. No warranty is given about the accuracy of the copy. Users should refer to the original published version of the material. 